\title{
1 The Panama Canal after a century of human impacts
}

2 Jorge Salgado*1,4,5, María I. Vélez², Catalina González-Arango ${ }^{1}$, Neil L. Rose ${ }^{3}$,

3 Handong Yang ${ }^{3}$, Carme Huguet ${ }^{6}$, Juan Camacho ${ }^{1}$ \& Aaron O'Dea

$4 \quad{ }^{1}$ Laboratorio de Palinología y Paleoecología Tropical, Departamento de Ciencias

5 Biológicas, Universidad de Los Andes, Carrera 1\# 18A - 12, Bogotá, Colombia.

$6{ }^{2}$ Department of Geology, University of Regina, 3737 Wascana Parkway, Regina,

7 Saskatchewan, S4S 0A2, Canada.

$8{ }^{3}$ Environmental Change Research Centre, Department of Geography, University

9 College London, Gower Street, London, WC1E 6BT, United Kingdom.

$10{ }^{4}$ Smithsonian Tropical Research Institute, PO Box 0843-03092, Balboa, Republic

11 of Panama

$12{ }^{5}$ Universidad Católica de Colombia, Avenida Caracas \# 46 -72, Sede Las Torres,

13 Bogotá, Colombia.

146 Departamento de Geociencias, Universidad de Los Andes, Carrera 1\#18A-12,

15 Bogotá, Colombia

16 *corresponding author: Jorge Salgado

17 Email: j.salgado@uniandes.edu.co

18 ORCID: https://orcid.org/0000-0003-0670-0334

19 Keywords: Climate change, tropical river damming, river flow, invasive species,

20 water pollution, hydrology, lake salinization 


\section{Abstract}

22 Large tropical river dam projects are set to accelerate over the forthcoming

23 decades to satisfy growing demand for energy, irrigation and flood control. When

24 tropical rivers are dammed, the immediate impacts are well studied, but the long-

25 term (decades-centuries) consequences of impoundment remain poorly known.

26 Here, we gather historical and paleoecological data from Gatun Lake, formed by

27 the building of the Gatun Dam (Panama Canal, Panamá) over 100 years ago, to

28 reconstruct the limnological evolution of the system in response to individual and

29 linked stressors (river damming, forest flooding, deforestation, invasive species,

30 pollution and hydro-climate). We found that after a century of dam construction

31 parallels associated with the natural hydrological functioning of river floodplains

32 persist. Hence, hydrology remains the most important temporal structural factor

33 positively stimulating primary productivity, deposition of new minerals, and

34 reduction of water transparency during wet periods. During dry periods, clear

35 water and aerobic conditions prevail and nutrients transform into available forms

36 in the detrital-rich reductive sediments. We highlight the importance of climate

37 change as an ultimate rather than proximate anthropogenic factor for sustainable

38 management options of tropical dams. 


\section{Introduction}

41 The tropics contain more than 4 million bodies of freshwater ${ }^{1}$ and many large

42 tropical rivers have been dammed for water management, commerce and energy

43 production ${ }^{2}$. Projections show a three-fold increase over the forthcoming decades

44 in the number of large dammed (>15 m high) tropical river projects ${ }^{3-5}$. When

45 rivers are dammed, the immediate impacts are well studied ${ }^{3}$. For instance, dams

46 transform carbon cycling ${ }^{6,7}$, alter river networks by creating artificial reservoirs ${ }^{3,8}$,

47 alter natural patterns of sediment transport ${ }^{8}$, impede upstream-downstream

48 movement of fish ${ }^{3}$ and modify water quality and productivity ${ }^{3,8}$. Yet almost

49 nothing is known about the long-term impacts and limnological evolution of

50 impoundment of highly diverse, tropical rivers. Rivers in the neotropics (the

51 tropical areas of North, Central and South America) are, in particular, poorly

52 studied $^{8,9}$ with almost no long-term continuous time-series of data for multiple

53 variables $^{10}$. This constrains our understanding on how these aquatic systems can

54 be sustainably managed in the long-term. In this study we combined exemplary

55 historical and paleoecological approaches to provide a continuous long-term

56 record of lake hydrology and geochemistry and the responses of different aquatic

57 biological groups associated with the iconic Panama Canal.

58 In 1913 the Chagres River was dammed, forming Gatun Lake on which the

59 Panama Canal is located (Fig. 1). At the time, Gatun Lake was the first

60 neotropical large dam and was the largest man-made lake in the world with a

61 surface area of $425 \mathrm{~km}^{2}$. In contrast, most neotropical dams are no older than a

62 quarter of century ${ }^{8,10}$ making Gatun Lake a unique opportunity to reveal long term 
63 dynamics in a tropical dam system. Moreover, Gatun Lake has extensive

64 environmental and ecological records thanks to monitoring and research

65 programs established by the Panama Canal Authority (ACP for its acronym in

66 Spanish) and the longstanding presence of the Smithsonian Tropical Research

67 Institute (STRI) in Panama. Combining these records that are unavailable for

68 other old dams, with paleoecological data offer therefore an unrivalled

69 opportunity to explore the impacts of damming on a tropical river over a period of

70 more than 100 years.

71 In this study, we present sedimentary data of Gatun Lake to build a biological

72 and environmental chronological sequence of changes and combined it with

73 historical water quality records (secchi depths, $\mathrm{pH}$, conductivity and dissolved

74 oxygen) available from 1969 to 2013, and on river annual flow and climate

75 (precipitation) records available from 1930 to 2013. The aim was to: (1)

76 reconstruct the limnological evolution of the Chagres River landscape (including

77 pre-impoundment times); and (2) assess individual and linked effects of river

78 damming, forest clearance and flooding, the introduction of invasive species,

79 water quality variation and climate on this aquatic landscape.

\section{Results}

82 Environmental history of Gatun Lake: The canal region experiences a

83 seasonal tropical monsoonal climate. Mean annual temperature across the canal

84 area is $26^{\circ} \mathrm{C}$ and mean monthly temperature varies by just $1^{\circ} \mathrm{C}$ annually ${ }^{11}$.

85 Rainfall ranges from around $1750 \mathrm{~mm}_{\text {year }}^{-1}$ mean annual precipitation on the 
86 Pacific coast, to $4000 \mathrm{~mm}_{\text {year }}{ }^{1}$ on the Caribbean coast ${ }^{12}$. Records beginning in

87 the late-1920s on the Smithsonian's Barro Colorado Island $(\mathrm{BCl})$ in the canal

88 show that annual rainfall has varied considerably between years, apparently

89 related to ENSO conditions ${ }^{13}$.

90 Gatun Dam led to flooding of large areas of tropical forest ${ }^{14}$, an increase in 91 sediment accumulation ${ }^{15}$ and, watershed deforestation ${ }^{16,17}$ for agriculture, in

92 addition to the operation of the canal and urban expansion ${ }^{17}$. Almost 20 years

93 later, another portion of rainforest was flooded across the river headwaters by the

94 construction of a second dam, Lake Alajuela, built to regulate the stochastic

95 hydrology of the Chagres $\operatorname{River}^{15}$ (Fig. 1). The consequences of forest flooding

96 have yet to be quantitatively assessed, but is likely that the expansive areas of

97 flooded allochthonous organic material would have contributed considerable

98 quantities of DOC into the newly formed lake $e^{6,7}$ facilitating large emissions of

99 greenhouse gases to the atmosphere, even decades after construction of the

100 dam, as has been shown in other tropical dams ${ }^{7,18}$.

101 Salinity of Gatun Lake has been historically below $0.2 \mathrm{ppt}^{19}$. However,

102 increases in salinity above the United States Environmental Protection Agency

103 (EPA) drinking water standards (>3.0 ppt) have been reported in the Miraflores

104 locks during the dry season since the completion of the Canal ${ }^{20}$. Furthermore, 105 recent (2004-2015) expansion of the canal has resulted in higher water demands

106 to operate a new set of larger locks resulting in more salt water penetrating the 107 lake, especially during the dry season ${ }^{20}$. The consequences of this emergent 108 salinization of Gatun Lake continue to be debated but observations of brackish 
water fauna, such as the non-native North American Harris mud crab (Rhithropanopeus harrisii) $^{21}$ and the Iraqi crab (Elamenopsis kempi) ${ }^{22}$, and

111 increases in observations of marine fish have already been reported in the lake ${ }^{23}$.

113 aquatic species. The Asian macrophyte Hydrilla verticillata was first recorded in

114 the lake around the 1930s, which rapidly dominated the lake after it was filled ${ }^{24}$.

115 Introduction of the peacock bass (Cichla ocellaris) to the lake in the late-1960s

116 caused a major ecological reorganization associated with dramatic declines in

117 native littoral planktivorous fish species ${ }^{25}$, and these impacts endure 45 years

118 later $^{23}$. Other known introductions have included the Asian bryozoan Asajirella

119 gelatinosa ${ }^{26}$, the Asian Melanoides (Thiara) tuberculata and, the South American

120 apple (Pomacea bridgesii) snail ${ }^{27}$. There are likely myriad other introductions that

121 have been undocumented or that are projected to occur under the new canal

122 expansion $^{28}$.

123 Paleoecological data: We focused our paleoecological analysis on three

124 biological groups from which fossil remains are commonly well preserved in lake

125 sediments: macrophytes, invertebrates (bryozoans, chironomids, cladocerans

126 and mollusks) and diatoms. As a measure of temporal environmental change we

127 combined information on the variation of single trace elements (potassium [K]-

128 river erosion; calcium [Ca]-salinity; lead [Pb], copper [Cu] and zinc [Zn]-

129 pollution) ${ }^{29}$ and elemental ratios (iron/magnesium [Fe/Mn]-reductive conditions;

130 titanium/calcium [Ti/Ca-detrital inputs] ${ }^{29}$. The carbon contribution of terrestrial

131 plants, macrophytes, and bacteria-algae was assessed through $n$-alkanes $\mathrm{C}_{15-}$ 
$132 \mathrm{C}_{31}$ biomarkers $^{30}$. The $n$-alkanes information was also used to calculate the

133 terrigenous aquatic ratio (TAR) and the submerged/floating aquatic macrophyte

134 inputs vs. emergent/ terrestrial plant input ratio (Pmar-aq) ${ }^{31}$. A methane index

135 (MI) ${ }^{32}$ was obtained via archaea-glycerol dialkyl glycerol tetraethers [GDGTs]).

136 Major zones of temporal change were assessed through clustering analysis and

137 the links between biological and environmental variation were tested via multiple

138 factor analysis-MFA ${ }^{33}$.

139 Core chronology and sedimentation rates: A sediment core $(87 \mathrm{~cm}$ long;

140 LGAT1) was retrieved from a littoral area $\left(9^{\circ} 2^{\prime} 49.58^{\prime \prime} \mathrm{N}, 79^{\circ} 50^{\prime} 6.33^{\prime \prime} \mathrm{W}\right)$ at a water

141 depth of approximately $1 \mathrm{~m}$ (Fig. 1). Sediments were dated using the constant

142 rate of ${ }^{210} \mathrm{~Pb}$ supply (CRS) model ${ }^{34}$ resulting in a chronology spanning the last

143 c.150 years (Fig. 2). The pre-canal riverine conditions were contained within the

$14487-50 \mathrm{~cm}$ of the core and the post-canal lake conditions within the top $50 \mathrm{~cm}$. The

145 age model showed that sedimentation rates at post-canal times remained

146 relatively uniform (each $\mathrm{cm}$ representing c. 8-15 years) until the early-2000s

147 when rates almost doubled (Fig. 2).

148 Long-term shifts in paleoecological proxies: Temporal variation on the

149 selected geochemical and biomarker data is presented in Fig. 2. Sixteen

150 macrophytes, 19 invertebrates and 81 diatom taxa (Figs. S1-S3) were identified

151 throughout the sediment core and summarized into functional groups according

152 to growth type (macrophytes), habitat preference (diatoms) and feeding mode

153 (invertebrates) as follows (Fig. 3): macrophytes submerged; anchored-floating; 
154 free-floating and emergent; invertebrates filter-feeders (bryozoans),

155 macrophyte/detrital (chironomids), shredders (Trichoptera cadis case larvae),

156 benthic (chironomids), and grazers (mollusks and cladocerans); diatoms

157 planktonic, benthic, littoral, aerophilous, and salinity-tolerant ${ }^{35,36}$. Diatom benthic

158 species were further sub-grouped into acidic, oligotrophic, benthic-mobile and

159 eutrophic species ${ }^{37-39}$.

160 Results uncover a dynamic aquatic history from before the formation of

161 Gatun Dam by the Panama Canal to the present day. As expected, results

162 describe over four main temporal zones of biological and environmental change a

163 gradual transition from a river-governed system to a lake system (Figs. 2,3).

164 During pre-canal times (Zone 1 c. pre-1870), the geochemical and biomarker

165 data reflected swamp-like alluvial conditions characterized by reductive

166 sediments (high $\mathrm{Ml}$ index and Fe/Mn ratio respectively), low nutrient and acidic

167 waters, and high detrital (Ti/Ca) inputs (Figs. 2,4). Before the creation of the

168 Panama Canal, the Chagres River meandered through an alluvial floodplain of

169 vast areas of swampy conditions ${ }^{13,40}$. In agreement with those records, we found

170 a prevalence of rushes and sedges, free-floating plant species (e.g. Ludwigia

171 sedoides, L. helminthorrhiza, Pistia stratiotes, Salvinia rotundifolia; Fig. S1) and

172 high occurrence of littoral and benthic diatoms (e.g. Eunotia, Encyonema and

173 Pinnularia; Fig. S3b) and charophyte macro algae (Chara spp. and Nitella spp.

174 Fig. S1), all of which commonly occur in low turbulence and low nutrient waters ${ }^{37-}$

17539,41 . The occurrence of planktonic diatoms (e.g. Aulacoseira spp., Fig. S3a)

176 further indicates an environment hydrologically connected to a main river 
177 channel ${ }^{37-39}$. Abundant Trichoptera shredders and macrophyte/detrital-associated

178 invertebrates (e.g. Cladopelma spp., Zavreliella spp., and Stenochironomus spp.;

179 Fig. S2) along with anaerobic bacteria-archaea all suggest a highly reductive

180 environment. In particular, the latter suggests that carbon cycling at the time

181 might have mainly occurred through methanogenesis and sulphate reduction

182 pathways ${ }^{42}$.

183 Construction of the Panama Canal led to a clear anthropogenic signal (Fig.

184 2). From 1870-1913 (Zone 2) pollutants such as $\mathrm{Cu}, \mathrm{Zn}$, and $\mathrm{Pb}$, previously

185 associated with mining activity, coal burning and gasoline combustion ${ }^{43}$,

186 increased considerably. These activities were most likely linked to the coal

187 combustion by large machinery used for the dredging and excavation of the

188 canal $^{40}$. Submerged (e.g. Najas guadalupensis, Najas marina, and

189 Ceratophyllum demersum; Fig. S1) and anchored-floating plants (likely

190 Nymphaea ampla), benthic-mobile diatoms (e.g. Navicula radiosa and Navicula

191 recens; Fig. S3c), caddisfly larvae (Trichoptera) shredders and bryozoan filter-

192 feeders (L. carteri, and Plumatella spp.) responded positively to these novel

193 conditions while diatoms shifted from littoral to benthic-planktonic associations

194 (Fig. 4). Increases in the bryozoans L. carteri and the colonizing A. gelatinosa in

195 particular, were likely responding to an expansion of macrophyte cover ${ }^{26,44}$. The

196 observed proliferation of caddisfly larvae may also have ultimately been driven by

197 increased detrital inputs and food availability as they prey on bryozoans ${ }^{44}$.

198 As the lake infilled after formation of the dam in 1913 (Zone 3), littoral detrital

199 (Ti/Ca) and river-fed elements (e.g. K) declined (Fig. 2). Declining erosion after 
200 dam construction likely continued following construction of the Alajuela Dam in

2011935 in the headwaters of the Chagres, reducing the supply of river material into

202 Gatun Lake ${ }^{15}$. However, contributions of allochthonous organic carbon (high TAR

203 index) increased up until the mid-1980s (Fig. 2). Possible sources of this

204 terrestrial carbon include the flooded forest areas ${ }^{13}$ and particulate material

205 derived from watershed deforestation, which peaked during the mid-1970s ${ }^{16}$.

206 These patterns of increasing terrestrial organic matter inputs from early-1920s to

207 the mid-1980s partially supports recent findings showing that the degradation of

208 flooded forest material in tropical impoundment projects may endure for decades

209 after reservoir infilling, a period when $\mathrm{CO}_{2}$ and $\mathrm{CH}_{4}$ production is commonly

210 facilitated $^{7,18}$. Yet, our data suggest that such carbon pathways may take even

211 longer to develop (four-five decades) than previously suggested for tropical dam

212 projects $^{7,18}$.

213 In general, our findings show that macrophyte growth was encouraged as the

214 lake infilled, promoting aerobic conditions (Fig. 4). This trend matches the

215 historical macrophyte records from Gatun Lake ${ }^{24}$, and other similar tropical

216 impoundment projects ${ }^{8,45}$. For instance, the invasion of $H$. verticillata that resulted

217 in many hectares of the lake becoming choked with this submerged species was

218 accompanied by increases in other submerged plants like Najas and

219 Ceratophyllum (Fi. S1). Free-floating plants, such as Eichhornia spp., and $P$.

220 stratiotes, also disseminated rapidly, while anchored plants ( $N$. alba in particular),

221 invertebrate shredders, filter-feeders and macrophyte/detrital associated taxa

222 declined (Fig. 3, Figs. S1,2.). 
223 Diatom and invertebrate assemblages mirrored the trends in macrophytes

224 following impoundment (Fig. 4). Over time, invertebrate communities shifted from

225 detrital to benthic associations, while bryozoan filter-feeders declined (Fig. 4),

226 which could have been a response to the gradual decline of anchored-floating

227 plants ${ }^{26,44}$. Diatoms shift to a benthic-aerophilous-saline diatom assemblage

228 characterized by increases Cocconeis placentula and N. amphibia, by

229 aerophilous genera such as Diadesmis, Luticola and Orthoseira and by the

230 salinity-tolerant species Terpsinoe musica, and Tabularia fasciculate ${ }^{35-37}$ (Fig.

231 S3). This shifts in diatom composition suggest that the progressive macrophyte

232 expansion provided an increase in habitat availability for benthic-mobile species

233 and suitable macrophyte littoral habitats for aerophilous species ${ }^{38,39}$ while

234 increases in saline-tolerant taxa were most likely driven by salt-water intrusions

235 from the passage of ships through the dam locks ${ }^{20}$ and ion runoff resulting from

236 deforestation ${ }^{16}$.

237 As the lake aged (post-1995; Zone 4) submerged and free-floating

238 macrophytes increased and carbon cycling shifted in concordance to within-lake

239 production (high Pmar-aq index value) ${ }^{31}$ (Fig. 2, 3). This shift in habitat structure

240 marked an upsurge in the abundance of grazing invertebrates and benthic diatom

241 species that prefer productive environments (fig. 2).

242 Impoundment and natural river floodplain dynamics: We found that after a

243 century of the dam construction, there are still remarkable parallels associated

244 with the natural hydrological functioning of a river floodplain system. In particular,

245 precipitation and annual river flow emerged as the most important factor driving 
246 most of both abiotic and biotic compartments (Fig. 4) in agreement with floods

247 and droughts being major drivers of river abiotic change and community

248 reorganization ${ }^{46}$. Shifts in hydro-climatic variables were suggested to alter a

249 series of interconnected processes such as sedimentation dynamics, water

250 quality, productivity, and sediment reductive/oxygenated conditions. During drier

251 periods for instance, sedimentation was relatively low due to lower physical

252 erosion while detrital inputs where high (Fig. 4). There was also a prevalence of

253 reductive sediments and relatively higher secchi depths ( $>3 \mathrm{~m})$, oxygenated

254 surface waters (> 6 ppm), higher conductance (>60 $\mu \mathrm{S} / \mathrm{cm})$ and higher nutrient

255 availability (Table 1; Fig. 4). Similar increases in conductance resulting from

256 reduced dilution of salt ions concentrations during the dry season have been

257 observed in the Amazon River, where conductance values in oxbow lakes can

258 increase up to 200 times the value of the main river ${ }^{46}$. Accumulation of organic

259 matter and debris in the lakebed causing reductive soil conditions have been also

260 described in the Paraná River system and attributable to low rates of water

261 circulation during drier phases ${ }^{47}$. The observed anoxic sediment conditions (high

262 Fe/Mn ratio) in Gatun, would have transformed nutrients (phosphorus in

263 particular) into more available forms ${ }^{42}$ that along with clearer and less variable

264 water levels would have favored planktonic diatoms ${ }^{37-39}$ and submerged and free

265 floating macrophytes ${ }^{45,47}$. As submerged plants grow in clearer waters they would

266 have also photosynthesized more increasing surface DO levels in the water ${ }^{48}$.

267 Wet periods positively stimulated sedimentation, deposition of new minerals

268 (e.g. Ca and K) and reduced water transparency (Fig. 4). Lower secchi depths 
269 were strongly linked to reductions in $\mathrm{pH}$, conductance and dissolved oxygen (Fig.

2704 ), which likely reflects the storage of organic matter during the dry phase,

271 coming from both autochthonous production and allochthonous inputs from the

272 lavish riparian vegetation surrounding the lake catchment ${ }^{47}$. A positive long-term

273 relationship between macrophyte productivity and wet periods also existed (Fig.

274 4). We attribute this increase in productivity to a decadal macrophytes

275 succession that was accompanied by increases in abundances and

276 representation of different plant taxonomic groups (Fig. S1). Furthermore, high

277 rates of river water exchange during high floods can act as a significant source of

278 propagules, especially for submerged and floating plants in neotropical rivers ${ }^{47}$.

279 The action of water transporting sediments and nutrient (TP and TN) additions

280 from surrounding soils, may promote further spatial heterogeneity in the lake ${ }^{46,47}$

281 opening up additional ecological niches for macrophytes and co-associated

282 benthic diatoms. Light attenuation in the water column coupled with fluctuation in

283 water levels may further stress the submerged vegetation while favoring

284 increases in floating macrophytes through enhanced nutrient input from the

285 flooded land ${ }^{45,47}$. The weak negative relationship between macrophyte

286 abundance and nutrient concentration (Fig. 4), suggests that primary productivity

287 in the lake may not yet be limited by nutrients. Moreover, changes in habitat

288 structures (anchored floating plants) rather than nutrient availability are

289 suggested to favor the variation of nutrient-rich associated benthic diatoms.

290 We are aware that the use of paleoecological data to infer past communities

291 and ecological responses has limitations as they can suffer from bias due to the 
292 differential production, transport and preservation of organismal remains ${ }^{49}$.

293 Nevertheless, our paleoecological data was in agreement with the historical

294 changes previously described for the lake. Uncertainties in the age model and

295 use of different historical environmental records might have also introduced some

296 discrepancies in our MFA model. Nevertheless, the observed limnological

297 changes agree with the literature of river floodplain dynamics ${ }^{46,47}$. This thesis is

298 further supported by the geochemical data that showed a coherent signal with

299 increases in precipitation over 2010-2011. We observed a drastic decline in Ca

300 coupled with increases in sedimentation rates, Fe/Mn, and Ti/Ca (Fig. 2), which

301 resemble the historical riverine pre-damming conditions and that are in

302 agreement with "La Purísima" rainstorm, which flooded the whole lake system

303 and increased sedimentation rates by almost 100 -fold ${ }^{50}$.

304 Is the Gatun Lake becoming more saline? Our data are concordant with a

305 gradual increase in salinity in some parts of Gatun Lake after the early-2000s as

306 observed by increases in saline-tolerant diatom species and Ca concentrations.

307 Seawater likely intrudes into the lake through the locks of the Panama Canal and

308 the deposit of ballast water into the lake, which was only forbidden after 1996.

309 The locks may not be the only reason for increasing salinity. Runoff associated

310 with the enclosed drainage basin and land-use change may have led to an

311 increase in ion input and hence increased water salinity. These two processes

312 are often governed not only by greater runoff but also by evaporation; a pattern

313 that is consistent with the peak in salinity-tolerant diatom species and increases

314 in emergent macrophytes during the drier period of the mid-1960s to mid-1980s 
315 (Figs. 3, 5b). The more recent increases in salinity-tolerant diatom species

316 (including two marine morphtypes; Fig. S3f) in the Gatun Lake after the early-

317 2000s implies an increase in the rate of salinization of the lake. This coincides

318 with the canal expansion work, which began in 2005 and the use of new locks

319 built to permit the transport of larger vessels (Post-Panamax) through the canal ${ }^{20}$.

320 These new locks use a tiered water sharing system that can more easily move

321 salt water up into the lake easier. Recent STRI salinity monitoring data supports

322 this inference (Steve Paton, pers. comm.). As deforestation in the lake catchment

323 has declined in the last two decades ${ }^{17,24}$, it is likely that runoff patterns might not

324 have been playing such an important role in salt intrusions in comparison to the 325 locks.

326 If the predicted drying of the canal area due to global climate change is 327 correct $^{12}$, and global shipping traffic increases ${ }^{28}$, it is likely that salinity will

328 continue to increase in the lake with major implications for drinking water ${ }^{17}$. The

329 ecological consequences of increased salinity has yet to be properly explored but

330 the recent increase we observe in $n$-alkane bacteria and both the $\mathrm{Ml}$ and Pmar-

331 aq indices could be a warning that the halocline will render surface sediments

332 anoxic ${ }^{51}$.

333 Ecological responses to fish invasion: The invasion of the apex predator

334 Cichla (peacock bass) into Gatun Lake in 1969 had a profound impact on the

335 native littoral planktonic fish community ${ }^{25}$, which resonate today with

336 marginalized native populations ${ }^{23}$. Zaret and Paine ${ }^{24}$ predicted that predation by

337 Cichla would also lead to cascading effects through the lake's food web, 
338 particularly on zooplankton (e.g. Ceriodaphnia), aquatic insects (e.g.

339 mosquitos/chironomids) and primary producers. Our results however do not

340 support the latter, as cladoceran ephippia only became apparent after the late

341 1990s, a period that instead coincides with increasing $n$-alkane algae

342 contribution. We found no evidence of increasing abundances or shifts in specific

343 functional groups (e.g. planktonic taxa) during or post-Cichla times that would

344 support evidence for a long-term cascading effect of predation down the food

345 web. Instead, evidence during this period points towards a bottom-up flow of

346 energy and nutrients coupled with asymmetric benthic-littoral production likely

347 associated with the development of macrophytes ${ }^{52}$.

349 Remarks and management options

350 Our data help reconstruct the biotic and abiotic dynamics of the Chagres River

351 landscape over the last $\sim 150$ years, providing a unique insight into the natural

352 and anthropogenic impacts of impoundment on tropical rivers. Species invasions,

353 land-use changes and ship traffic have impacted the lake's ecosystem. Yet, our

354 multiple lines of evidence emphasize that the system still retains some of the

355 natural riverine functions on a decadal scale. It is however anticipated that

356 climate change will modify precipitation, evapotranspiration, and runoff in the

357 tropics $^{12}$. Thus, increasing drier and wetter periods could fundamentally modify

358 the functioning of Gatun Lake. Drier periods will likely encourage the on-going

359 spread of Hydrilla and Eichhornia and increases in salinity via reduced dilution.

360 Wetter periods in turn, may stimulate sedimentation rates, nutrient inputs, salt 
361 intrusions from storm surges and floating plant dominance. Many neotropical

362 impoundment projects have become highly eutrophic within a few decades,

363 rapidly overriding the importance of hydrology $8,10,45$. However, Gatun Lake stands

364 apart, by having high precipitation rates (annual mean $>2.200 \mathrm{~mm}$ ), a unique

365 occurrence of large extensions of protected forest areas (e.g. Barro Colorado

366 Natural Monument and Soberanía) in the lake catchment, and large quantities of

367 water leaving the system (>1 million $\mathrm{m}^{3} /$ year $)^{53}$ every time a ship pass through

368 the lake locks. These factors may provide some buffering, helping to reduce

369 shifts in runoff, water pollution and maintaining the natural hydrological balance

370 under a changing climate. Our study emphasizes that to preserve natural riverine

371 system functioning in tropical impoundment projects, management activities must

372 not only include better design and management of flow releases ${ }^{3}$ but also the

373 understanding of key long-term natural ecosystem structural drivers such as river

374 flow, runoff patterns and water exchange rates.

\section{Materials and Methods}

377 Study area: Gatun Lake is situated in the valley of the Chagres River to the 378 south of Colón, Panama $\left(9^{\circ} 11^{\prime} \mathrm{N} 79^{\circ} 53^{`} \mathrm{~W}\right)$ (Fig. 1). It is an artificial large lake $379\left(425 \mathrm{~km}^{2}\right)$ with a maximum water depth of $30 \mathrm{~m}$ and extensive areas of shallow 380 water $(<5 \mathrm{~m})$. The lake waters are well mixed throughout much of the dry (mid-

381 December to mid-April) and wet (mid-April to mid-December) season ${ }^{53}$. The lake 382 level is $26 \mathrm{~m}$ above sea level storing $5.2 \mathrm{~km}^{3}$ of water ${ }^{53}$. It serves a dual purpose, 383 as a channel facilitating global trade and cross-oceanic travel, and as a 
384 freshwater reservoir (Gatun Lake) providing a water supply to Panamá City and

385 other towns ${ }^{17}$.

386 Sampling: A sediment core (87 cm long; LGAT1) was retrieved in 2013 from

387 near "La Represa" village in the southeast area of the lake (Fig. 1). The basin

388 offered an ideal coring site given that it lies outside the dredging zone of the

389 canal and is located in one of the most deforested areas of the lake watershed.

390 The core (LGAT1) was retrieved from a littoral area $\left(9^{\circ} 2^{\prime} 49.58^{\prime \prime} \mathrm{N}, 7^{\circ} 50^{\prime} 6.33^{\prime \prime} \mathrm{W}\right.$;

391 Fig. 1) at a water depth of approx. $1 \mathrm{~m}$. We used a modified Livingstone Piston

392 Sampler of $4 \mathrm{~cm}$ diameter. Sediment samples were extruded in the field at $1 \mathrm{~cm}$

393 intervals.

394 Core dating: Fourteen dried sediment samples from core LGAT1 were analyzed

395 for ${ }^{210} \mathrm{~Pb},{ }^{226} \mathrm{Ra},{ }^{137} \mathrm{Cs}$ and ${ }^{241} \mathrm{Am}$ by direct gamma assay in the Environmental

396 Radiometric Facility at University College London, using ORTEC HPGe GWL

397 series well-type coaxial low background intrinsic germanium detector. The

398 sedimentary chronology was determined using the Constant Rate of Supply

399 model $(\mathrm{CRS})^{34}$.

400 Geochemical elements: Elemental composition on 1cm-thick discrete samples

401 was measured via X-Ray Fluorescence (XRF) on a handheld XRF analyzer

402 spectrometer, XMET 7500. Dry sediment samples were ground and

403 homogenized using a mortar and pestle. Three g of sediment sample were used

404 and covered with a Chemplex thin-film sample support. The handheld XRF

405 analyzer spectrometer was calibrated against certified material prior to analysis 
406 and mean values for each element were determined from duplicate

407 measurements. Sampling resolution was at $2-\mathrm{cm}$ intervals for the top $50 \mathrm{~cm}$ of

408 the core and at 4-cm for the remainder. A total of 34 samples were analyzed.

409 Calcium (Ca), potassium (K), iron (Fe), manganese (Mn), titanium (Ti), lead (Pb),

410 copper $(\mathrm{Cu})$ and zinc $(\mathrm{Zn})$ data were selected for this study. The elements $\mathrm{Pb}, \mathrm{Cu}$

411 and $\mathrm{Zn}$ were used as proxies for human-derived pollution events, Ca as a proxy

412 of marine influence, and $\mathrm{K}$ as a proxy of physical erosion ${ }^{56}$. We calculated

413 complementary index ratios to investigate changes in reduction conditions

414 (Fe/Mn) and detrital input (Ti/Ca. $)^{29}$.

415 Biomarkers: We analyzed $n$-alkanes composition in 10 sediment samples ${ }^{30}$. We

416 used $n$-alkanes $\mathrm{C}_{15}-\mathrm{C}_{31}$, as indicators of terrestrial plants, macrophytes, and

417 bacteria-algae ${ }^{30}$. Compounds were measured with a Shimazu GC-2010 gas

418 chromatograph interfaced to a Shimazu GCMS-QP2010 (see ref-58 for detailed

419 methodology).

420 Besides relative $n$-alkane contribution, we also calculated the terrigenous

421 aquatic ratio (TAR), which quantifies the in situ algal vs. terrestrial organic

422 matter ${ }^{31}$ and the submerged/floating aquatic macrophyte inputs vs. emergent/

423 terrestrial plant input ratio (Pmar-aq) ${ }^{31}$. The Pmar-aq quantifies the non-emergent

424 aquatic macrophyte input to lake sediments relative to that from the emergent

425 aquatic and terrestrial plants ${ }^{31}$. Values of Pmar-aq $<0.1$ corresponds to terrestrial

426 plants, of 0.1-0.5 to emergent macrophytes and of $>0.5-1$ to submerged/floating

427 macrophytes ${ }^{31}$. 
428 The methane index $(\mathrm{MI})$ that quantifies the relative contribution of

429 methanotrophic Euryarchaeota against ammonia oxidizing Thaumarchaeota was

430 also calculated ${ }^{32}$. Ml values close to 1.0 indicate anaerobic environments,

431 whereas values close to zero indicate aerobic conditions ${ }^{32}$. To calculate the MI

432 index we measured glycerol dialkyl glycerol tetraethers (GDGTs) using an Agilent

4331260 UHPLC coupled to a 6130 quadrupole MSD high performance liquid

434 chromatography-atmospheric pressure chemical ionization-mass spectrometry

435 (HPLC-APCI-MS).

436 Plant and invertebrate macrofossil: We analyzed 23 sediment samples for

437 plant and invertebrate remains. Between 2-4 g of dried sediment material per

438 sample were used and all samples were disaggregated in $10 \%$ potassium

439 hydroxide $(\mathrm{KOH})$ before sieving. Macrophyte fossils were retrieved from the

440 residues of sieved core material (using mesh sizes of $355 \mu \mathrm{m}$ and $125 \mu \mathrm{m}$ )

441 following standard methods ${ }^{54}$. Plant macrofossil data were standardized as the

442 number of fossils per $100 \mathrm{~cm}^{3}$ and identified by comparison with reference

443 material and by using relevant taxonomic keys ${ }^{54}$. Due to poor preservation of

444 Hydrilla remains, we estimated temporal abundances through its well-

445 documented historical records ${ }^{23}$ and expressed in a $0-3$ scale, where 0 is absent

446 and 3 highly abundant. All macrophyte taxa were then classed based on

447 preferred growth-type as submerged; anchored-floating; free-floating and

448 emergent. Invertebrate taxa were classed according to feeding behavior or

449 preferred habitat as: filter-feeders (bryozoans); macrophyte/detritus 
450 (chironomids), shredders (Trichoptera larvae); benthic (chironomids), and grazers

451 (mollusks and cladocerans).

452 Diatoms: Twenty-three samples were analyzed for diatoms following standard

453 procedures by Battarbee et al. ${ }^{55}$. The diatom suspension was mounted on slides

454 with Naphrax ${ }^{\circledR}$ after the removal of carbonates by $\mathrm{HCl}$ and organic matter by

$455 \mathrm{H}_{2} \mathrm{O}_{2}$. Diatom taxonomy and ecology mainly followed Diatoms of North America

456 (https://diatoms.org). Diatom species were classed based on preferred habitat

457 type as planktonic, benthic, littoral and aerophilous, and as salinity-tolerant.

458 Benthic species were sub grouped into acidic-oligotrophic, eutrophic, and mobile

459 species. For each sediment sample, we counted a minimum of 400 valves.

460 Historical environmental archives: Historical data on water quality and hydro-

461 climatic variables are presented in Table 1. Long-term hydro-climatic, i.e.

462 precipitation (three and five years average) and river annual discharge data, from

4631930 to 2013 were obtained from the monitoring division of STRI (Steve Paton,

464 pers. comm.) and the Panama Canal Authority (23). Long-term physical and

465 chemical variables from 1969-2013 (pH, conductivity, dissolved oxygen [DO],

466 total nitrogen [TN], total phosphorous [TP], chlorophyll a [Chl-a] and secchi

467 depth) were obtained from literature ${ }^{56,57}$ and from the ACP Water Quality

468 Monitoring Division reports ${ }^{57}$. For the ACP data we used the average annual

469 values of each selected variable recorded at two sampling stations (Laguna Alta-

470 LAT and Toma de Agua Represa-TAR) located near our coring site area. 
471 Data analysis: A stratigraphic plots of the study biological functional groups were

472 achieved using the "Rioja" Package in $\mathrm{R}^{58}$. Major zones of change were

473 achieved through clustering analysis. To summarize and visualize the most

474 important gradients of temporal change in the different biological functional

475 groups, environmental variables, and historical data we used multiple factor

476 analysis (MFA) ${ }^{33}$ in $\mathrm{R}$ (Factoextra and FactoMiner packages in R). This analysis

477 is a multivariate technique in which individuals (core depths) are described by

478 several sets of variables (quantitative in our case) structured into groups. The

479 analysis takes into account the contribution of all groups of variables to define the

480 distance between core depth samples. Variables within a group were normalized

481 by applying a weight equal to the inverse of the first eigenvalue of the analysis of

482 the group 33 .

We ran two separate MFA analyses according to data availability. The first

484 analysis focused on the historical hydro-climatic variables (river flow and

precipitation; $n=15$ data points) and all paleoecological data spanning since pre-

canal times and clustered into five major groups: macrophytes (submerged,

487 anchored-floating, free-floating and emergent; $n=23$ data points for each group),

488 diatoms (littoral, benthic, planktonic, salinity-tolerant, and aerophil; $n=23$ data

489 points for each group), invertebrates (filter-feeders, shredders, benthic,

490 macrophyte/detritus and grazers; $n=23$ data points for each group), geochemical

491 elements and ratios ( $n=23$ data points for each element or ratio), and biomarkers;

492 ( $n=10$ data points for each parameter). Missing information at given time-periods

493 for biomarkers (10 samples analyzed) and hydro-climatic data (spanning from 
494 1930-2013), was replaced in the MFA by the mean of each variable ${ }^{33}$. The

495 second MFA focused on the time-period 1969-2013 from which historical water

496 quality data $(\mathrm{pH}$, conductivity, phosphorous, chlorophyll-a, and secchi depths;

$497 \mathrm{n}=13$ data points) was available (Table 1). For this analysis we included the

498 historical hydro-climatic data ( $n=13$ data points) and the paleoecological groups

499 data ( $n=13$ data points for each biological and geoechemical group), excepting

500 biomarkers (too limited number of samples), from analysis 1 . To quantify the

501 contribution of each variable in the MFA maps we used the argument col.var =

502 "contrib" (Factoextra package, R). Prior to MFAs we run exploratory principal

503 component analyses (PCA) to detect uninformative or redundant historical water

504 quality variables (see Fig. S4 for details). As a first step we discarded nitrates

505 due to low variation (Fig. S4b) and subsequently, we discarded phosphates and

506 chl-a as these two variables showed a strong correlation with DO at the water

507 surface (positive) and with DO in the water column (negative) respectively (Fig.

508 S4c). We left both DO measurements instead of nitrates and chl-a due to a better

509 historical record (see Table 1).

510 Data Availability: all relevant data are available from the authors and the data

511 will be deposit in a public repository.

\section{Acknowledgments}

514 We thank the Smithsonian Tropical Research Institute (STRI) for funding

515 fieldwork and supporting JS through a Short-term Postdoc Fellowship. We thank 
516 Dr. Dolores Piperno at STRI, for lending us the coring device. We thank

517 Universidad de Los Andes and COLCIENCIAS for supporting JS under the

518 postdoctoral program "Es tiempo de volver" Convocatoria 2015. We also thank

519 Vicerrectoria de Investigaciones of Universidad de Los Andes, for supporting one

520 month of salary for JS. We thank the Bloomsbury Environmental Isotope Facility

521 at University College London for sediment dating. We thank Victor Frankel, Felix

522 Rodriguez, Luis J. de Gracia, Marcos Alvarez, Maria Pinzon and Marcela Herrera

523 for fieldwork, laboratory assistance and hospitality. We thank the Geociencias

524 Laboratory at Universidad de los Andes for facilitating the XRF analyzer and

525 Laura Caceres for analyzing the XRF data. We thank Steve Paton for historical

526 climatic data provision. We want to thank Professors J.-H. Kim and K.-H. Shin for

527 the measurement of the biomarkers in their laboratory at the University of

528 Hanyang, South Korea. The collection and exporting of sediment material was

529 assessed under the ARAP collecting permit No. 25.

530 Author Contributions: JS designed the study and collected the sediment

531 material. JS produced and analyzed the plant and invertebrate macrofossil data,

$532 \mathrm{CH}$ and JC produced and analyzed the biomarker data, and MV produced and

533 analyzed the diatom data. NR and HY produced and analyzed the

534 lithostratigraphic and radiometric data. JS wrote the first manuscript and all

535 authors contributed substantially for the final version.

536 Competing interests: The authors declare no competing financial interests. 


\section{References}

538 1. Verpoorter, C., Kutser, T., Seekell, D. A. \& Tranvik, L. J. A global inventory

539 of lakes based on high-resolution satellite imagery. Geophysical Research

$540 \quad$ Letters 41, 6396-6402 (2014).

541 2. Grill, G. et al. Mapping the world's free-flowing rivers. Nature 569, 215-

$221(2019)$.

543 3. Poff, N. L. \& Schmidt, J. C. How dams can go with the flow. Science 353,

$544 \quad 1099-1100(2016)$

545 4. Gleick, P. H. Global Freshwater Resources: Soft-Path Solutions for the

546 21st Century. Science 302, 1524-1528 (2003).

547 5. Zarfl, C., Lumsdon, A. E., Berlekamp, J., Tydecks, L. \& Tockner, K. A

$548 \quad$ global boom in hydropower dam construction. Aquatic Sciences 77, 161-

$549 \quad 170(2014)$.

550 6. Maavara, T., Lauerwald, R., Regnier, P. \& Van Cappellen, P. Global

551 perturbation of organic carbon cycling by river damming. Nature

$552 \quad$ Communications 8, 15347 (2017).

553 7. Tranvik, L. J. et al. Lakes and reservoirs as regulators of carbon cycling

554 and climate. Limnology and Oceanography 54, 2298-2314 (2009).

555 8. Agostinho, A. A., et al. Patterns of colonization in neotropical reservoirs,

556 and prognoses on aging, in Theoretical Reservoir Ecology and its 

(1999).

9. Carvajal-Quintero, J. D. et al. Damming Fragments Species' Ranges and Heightens Extinction Risk. Conservation Letters 10, 708-716 (2017). reservoirs: challenges and implications for management. Journal of Paleolimnology (2019). tropical: ciclos estacionales y cambios a largo plaza, Jr., E. G. Leigh, A. S. Rand, D. M. Windsor, Eds. Smithsonian Tropical Research Institute, Panamá, pp. 53-71 (1995).

12. Engelbrecht, B. M. J. et al. Drought sensitivity shapes species distribution patterns in tropical forests. Nature 447, 80-82 (2007). population dynamics of free-standing figs in a maturing forest. PLOS ONE of Sustainable Forestry 8, 81-91 (1999). 
579 16. Wadsworth, F. H. Deforestation: death to the Panama Canal,

580 in Proceedings of the US Strategy Conference on Tropical Deforestation.

$581 \quad$ (US Department of State and US Agency for International

582 Development, 1978), pp. 22-24.

583 17. Condit, R. et al. The Status of the Panama Canal Watershed and Its

584 Biodiversity at the Beginning of the 21st Century. BioScience 51, 389

$585 \quad$ (2001).

586 18. Campo, J. \& Sancholuz, L. Biogeochemical impacts of submerging forests

587 through large dams in the Río Negro Negro, Uruguay. Journal of

588 Environmental Management 54, 59-66 (1998).

589 19.Jongeling, T., Hulsbergen, R., \& Schwanenberg, D. Water Quality Model

590 of Gatun Lake for Expanded Panama Canal. Part I Modelling of the

591 present situation, in Q3959 report, WL | Delft Hydraulics, pp. 1-224

592 (2008).

593 20.Wijsman, J. W. M. Panama Canal Extension: A review on salt intrusion

594 into Gatun Lake, in report No. C215/13, (IMARES Wageningen UR, 2013),

$595 \quad$ pp. 1-27 (2013).

596 21.Roche, D. G., Torchin, M. E., Leung, B. \& Binning, S. A. Localized

597 invasion of the North American Harris mud crab, Rhithropanopeus harrisii,

598 in the Panama Canal: implications for eradication and spread. Biological

$599 \quad$ Invasions 11, 983-993 (2008). 
600

601

602

603

22. Kam, Y., Schlöder, C., Roche, D. \& Torchin, M. The Iraqi crab, Elamenopsis kempi in the Panama Canal: distribution, abundance and interactions with the exotic North American crab, Rhithropanopeus harrisii. Aquatic Invasions 6, 339-345 (2011).

23. Sharpe, D. M. T., De León, L. F., González, R. \& Torchin, M. E. Tropical fish community does not recover 45 years after predator introduction. Ecology 98, 412-424 (2017).

24. ACP-Autoridad del Canal de Panamá. Agua y Bosques en la cuenca del canal: tendencias de largo plazo. Autoridad del Canal de Panamá, Departamento de Ambiente, Agua y Energía, Canal de Panamá, pp. 1-59 (2012)

25. Zaret, T. M. \& Paine, R. T. Species Introduction in a Tropical Lake: A newly introduced piscivore can produce population changes in a wide range of trophic levels. Science 182, 449-455 (1973).

26. Wood, T. S. \& Okamura, B. Asajirella gelatinosa in Panama: a bryozoan range extension in the Western Hemisphere (Ectoprocta: Phylactolaemata). Hydrobiologia 390, 19-23 (1998).

27. Angehr, G. R. Rapid long-distance colonization of Lake Gatun, Panama, by snail kites. Wilson Bulletin 111, 265-268 (1999).

28. Muirhead, J. R., Minton, M. S., Miller, W. A. \& Ruiz, G. M. Projected effects of the Panama Canal expansion on shipping traffic and biological invasions. Diversity and Distributions 21, 75-87 (2014). 
622

623

624

625

626

627

628

629

630

631

632
29. Davies, S. J. Lamb, H. F. \& Roberts, S. J. Micro-XRF core scanning in palaeolimnology: recent developments, in Micro-XRF Studies of Sediment Cores, I. W. Croudace, R. G. Rothwell, Eds Springer, pp. 189-226 (2015).

30. Eglinton, T. I. \& Eglinton, G. Molecular proxies for paleoclimatology. Earth and Planetary Science Letters 275, 1-16 (2008).

31. Ficken, K., Li, B., Swain, D., \& Eglinton, G. An n-alkane proxy for the sedimentary input of submerged/floating freshwater aquatic macrophytes. Organic Geochemistry 31, 745-749 (2000).

32. Zhang, Y. G. et al. Methane Index: A tetraether archaeal lipid biomarker indicator for detecting the instability of marine gas hydrates. Earth and Planetary Science Letters307, 525-534 (2011).

33. Pagès J. Analyse factorielle multiple appliquée aux variables qualitatives et aux données mixtes. Revue de statistique appliquée 50, 5-37 (2002).

34. Appleby, P. G. et al. 210Pb dating by low background gamma counting. Hydrobiologia 143, 21-27 (1986).

35. Potapova, M. \& Charles, D. F. Distribution of benthic diatoms in U.S. rivers in relation to conductivity and ionic composition. Freshwater Biology 48, $1311-1328$ (2003).

36. Rovira, L., Trobajo, R. \& Ibáñez, C. The use of diatom assemblages as ecological indicators in highly stratified estuaries and evaluation of existing diatom indices. Marine Pollution Bulletin 64, 500-511 (2012). 
37. Fayó, R., Espinosa, M. A., Vélez-Agudelo, C. A., Pan, J. \& Isla, F. I. Diatom-based reconstruction of Holocene hydrological changes along the Colorado River floodplain (northern Patagonia, Argentina). Journal of Paleolimnology 60, 427-443 (2018).

38. Reid, M. A., Chilcott, S. \& Thoms, M. C. Using palaeoecological records to disentangle the effects of multiple stressors on floodplain wetlands. Journal of Paleolimnology 60, 247-271 (2017).

39. Gell, P. \& Reid, M. Assessing change in floodplain wetland condition in the Murray Darling Basin, Australia. Anthropocene 8, 39-45 (2014).

40. McCullough, D. The path between the seas: the creation of the Panama Canal, 1870-1914, (Simon and Schuster, 2001), pp. 1-698.

41. Kolada, A. et al. The applicability of macrophyte compositional metrics for assessing eutrophication in European lakes. Ecological Indicators 45, 407-415 (2014).

42. Tabacchi, E. et al. Development, maintenance and role of riparian vegetation in the river landscape. Freshwater Biology 40, 497-516 (1998).

43. Miller, H. et al. A 500 Year Sediment Lake Record of Anthropogenic and Natural Inputs to Windermere (English Lake District) Using Double-Spike Lead Isotopes, Radiochronology, and Sediment Microanalysis. Environmental Science \& Technology 48, 7254-7263 (2014). 
44. Ricciardi, A. \& Reiswig, H. M. Taxonomy, distribution, and ecology of the freshwater bryozoans (Ectoprocta) of eastern Canada. Canadian Journal of Zoology 72, 339-359 (1994).

45. Scheffer, M. et al. Floating plant dominance as a stable state. Proceedings of the National Academy of Sciences 100, 4040-4045 (2003).

46. Junk, W. J., Bayley, P. B., \& Sparks, R. E. The flood pulse concept in river-floodplain systems. Cannadian Journal of Fisheries and Aquatic Sciences 106, 110-127 (1989).

47.Sousa, W. T. Z., Thomaz, S. M. \& Murphy, K. J. Drivers of aquatic macrophyte community structure in a Neotropical riverine lake. Acta Oecologica 37, 462-475 (2011).

48. Spence, D. H. N. \& Chrystal, J. Photosynthesis and zonation of freshwater macrophytes. I. Depth distribution and shade tolerance. New Phytologist $69,205-215$ (1970).

49. Clarke, G. H. et al. Representation of aquatic vegetation change by plant macrofossils in a small and shallow freshwater lake. Vegetation History and Archaeobotany 23, 265-276 (2014).

50. ACP-Autoridad del Canal de Panamá, Informe sobre la tormenta la Purísima 2010. División de Agua Sección de Recursos Hídricos, Canal de Panamá, pp. 1-163 (2014).

51. Mead, R., Xu, Y., Chong, J. \& Jaffé, R. Sediment and soil organic matter source assessment as revealed by the molecular distribution and carbon 

(2005).

52. Schindler, D. E. \& Scheuerell, M. D. Habitat coupling in lake ecosystems. Oikos 98, 177-189 (2002).

53. Zaret, T. M. Central American limnology and Gatún Lake. Panama”, in: Lakes and reservoirs. Ecosystems of the world, F.B. Taub Ed. Elsevier, pp. $447-465$ (1984). Lake Sediments, Vol. 3: Terrestrial, Algal and Siliceous Indicators, J. P. Smol, H. J. B. Birks, Eds. Kluwer, 2001, pp. 49-74 (2001). vol 3, J. P. Smol, H.J.B. Birks, W. M. Last, R. S. Bradley, K. Alverson,

56. Gutiérrez, R., et al Inventario biológico del canal de Panamá: estudio de aguas continentales. Scientia 4, 17-81 (1995).

57. ACP- Autoridad del Canal de Panamá, Informes de calidad del agua, (Canal de Panamá, 2003-2013), Autoridad del Canal de Panamá, 2013): available online at: https://micanaldepanama.com/nosotros/cuenca-hidrografica/ 
bioRxiv preprint doi: $h$ ttps://doi org/10.1101/777938; this version posted September 23, 2019. The copyright holder for this preprint (which was not certified by peer review) is the author/funder, who has granted bioRxiv a license to display the preprint in perpetuity. It is made available under aCC-BY-NC-ND 4.0 International license.

706 58. Juggins, S. Rioja: Analysis of Quaternary Science Data. R package

707 version 0.5-6 (2009). Available online at: http://cran.r-

708 project.org/package=rioja

709 


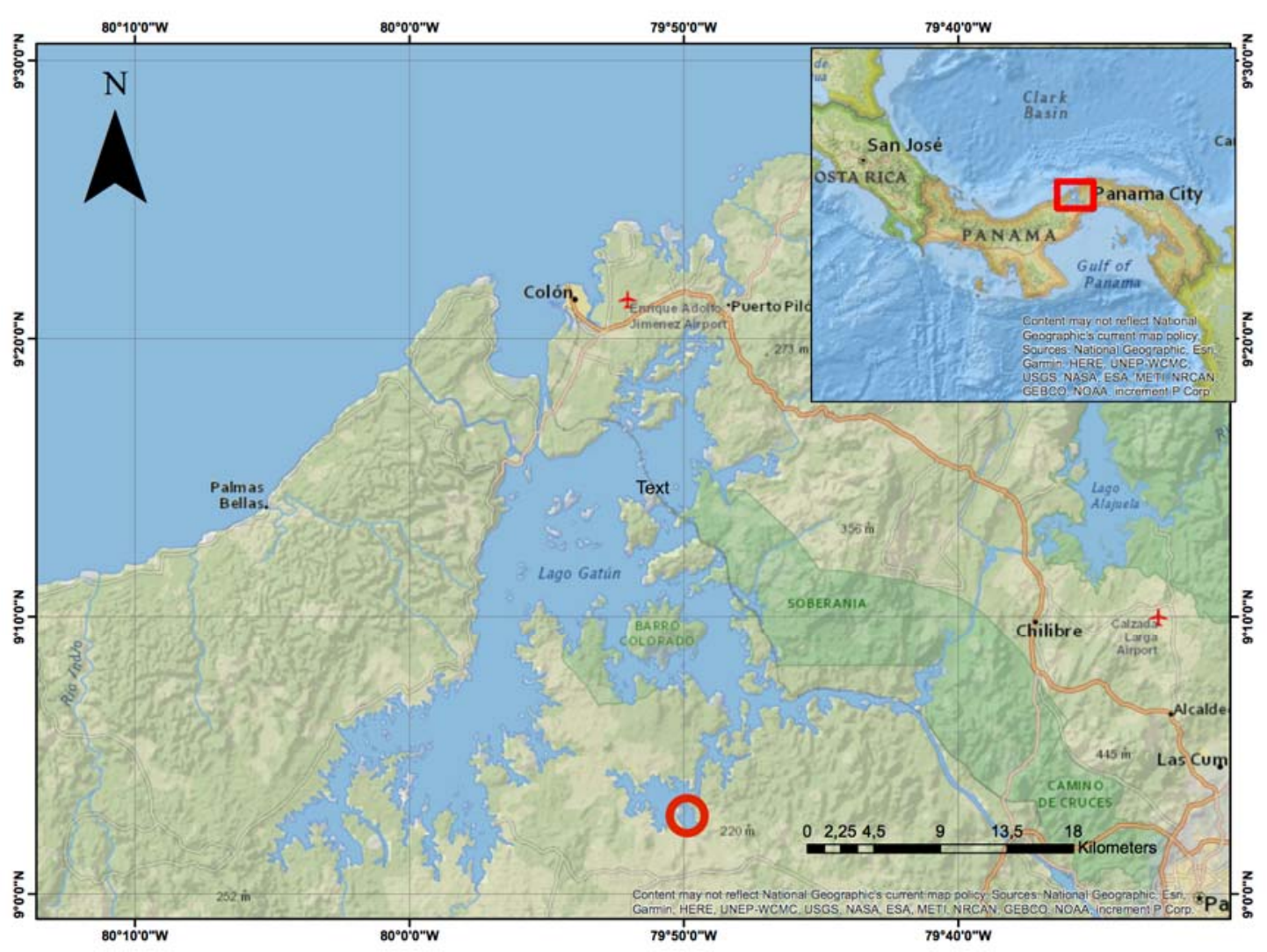

712 Figure 1. Map of the River Chagres watershed. The artificial Gatun and

713 Alajuela lakes and the connecting River Chagres are indicated in blue. A red

714 circle shows the coring location of LGAT1 core. Natural protected areas are

715 shown in dark-green. 

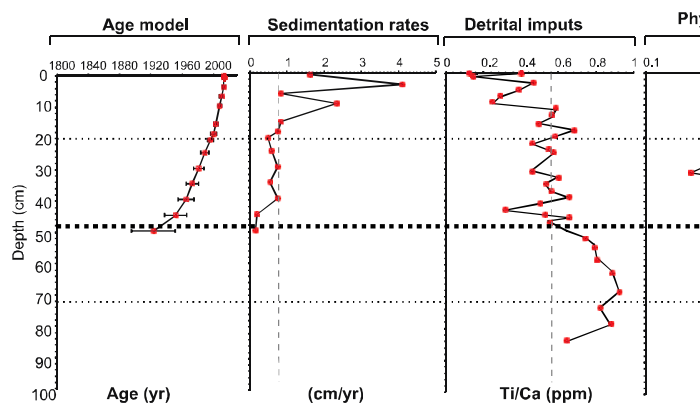

Physical erosion

Salinity inputs Reductive conditions

$\mathrm{Ti} / \mathbf{C a}(\mathbf{p p m})$ $0.2 \underbrace{0.3 \quad 0.4}$
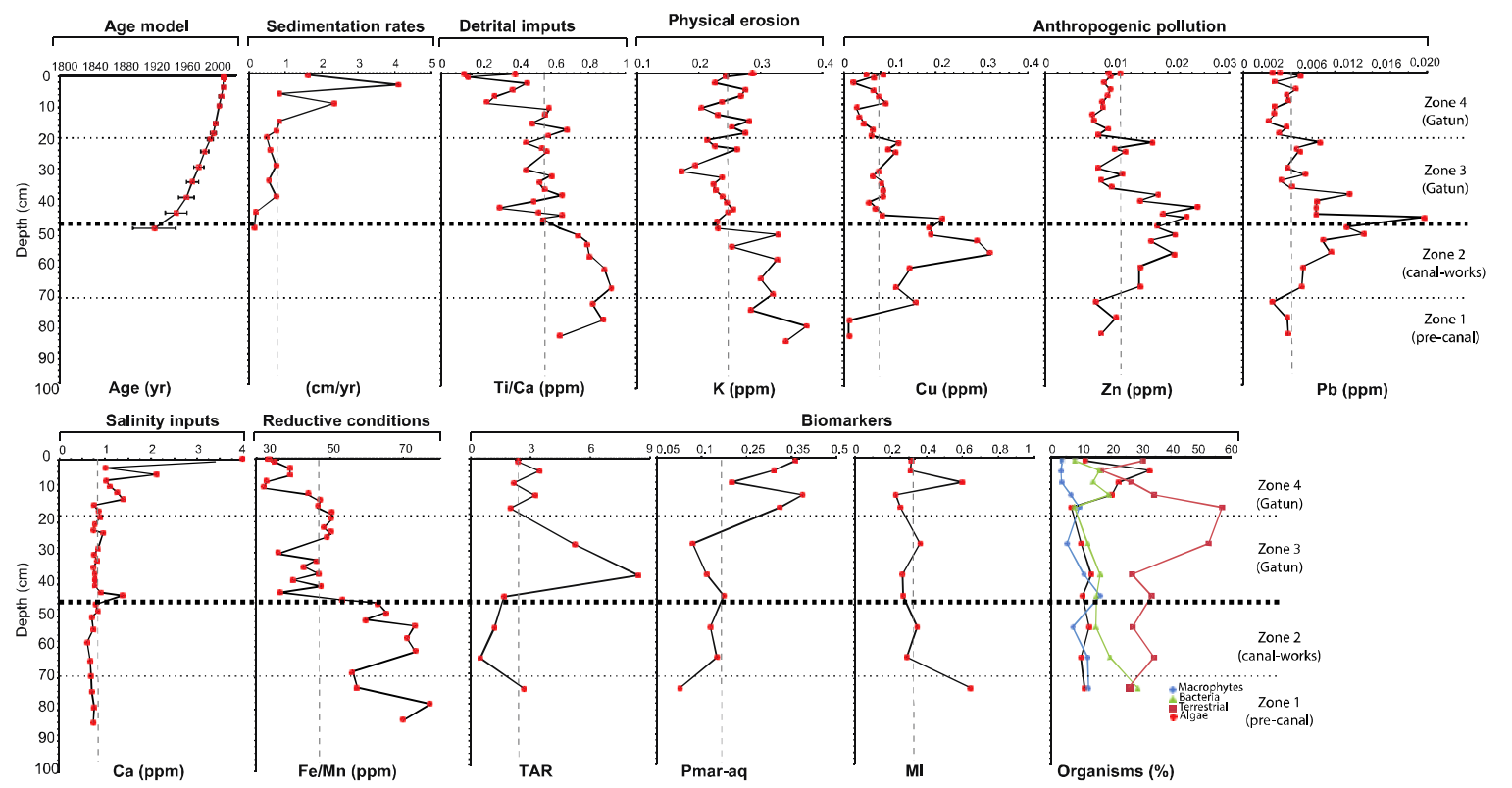

$\mathrm{K}(\mathrm{ppm})$

$\mathrm{Cu}(\mathrm{ppm})$

$\mathrm{Zn}(\mathrm{ppm})$

$\mathrm{Pb}$ (ppm)

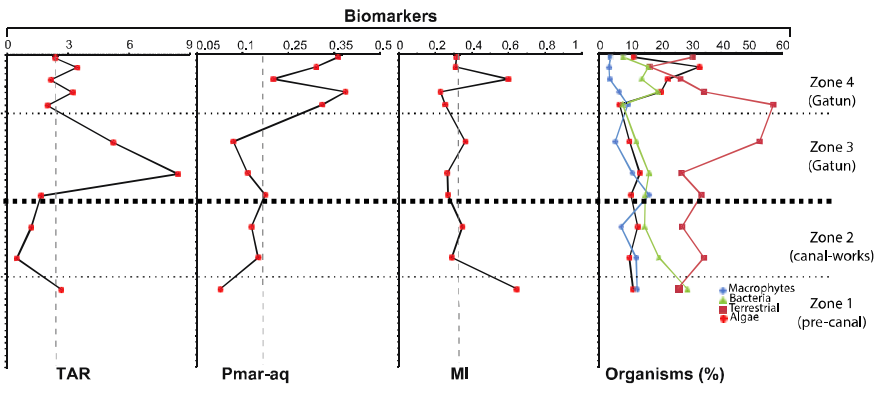

719 Figure 2. Sedimentary profile of the ${ }^{210} \mathrm{~Pb}$ age model (dates and ages and

720 standard deviations are presented), sedimentation rates, selected

721 geochemical elements and ratios, and biomarkers indices in LGAT1

722 sedimentary core. Terrigenous aquatic ratio-TAR; Methane Index -MI; the

723 submerged/floating aquatic macrophyte inputs vs. emergent/ terrestrial plant

724 input ratio-Pmar-aq. Major temporal zones of change determined by clustering

725 analysis, corresponding to Zone 1 c. pre-1870, Zone 2 c.1870-1914, Zone 3

726 1923-1990, and Zone 4 1991-2013. A vertical grey dotted line indicates the mean

727 value of each parameter.

728

729 


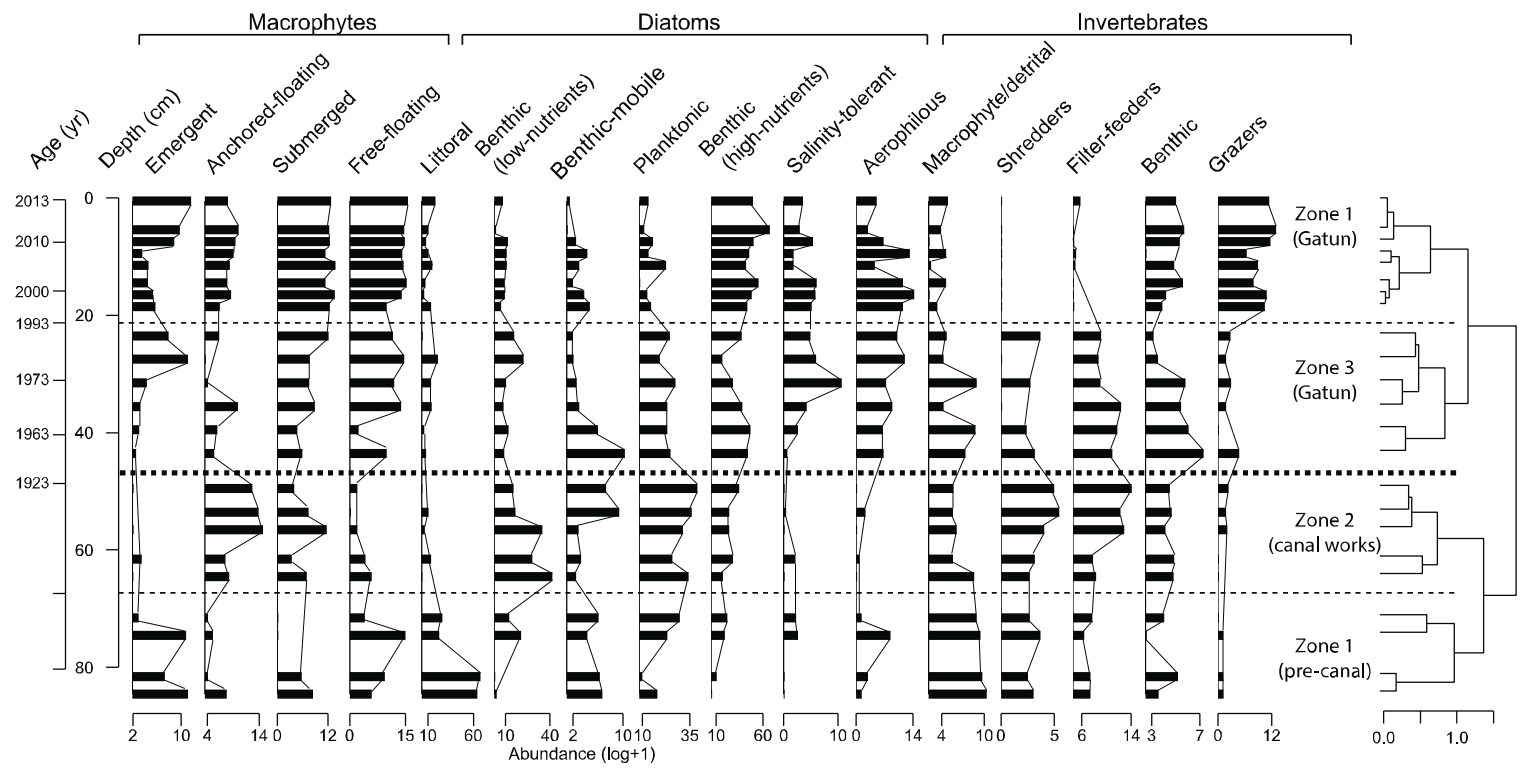

731 Figure 3. Sedimentary profile of the study biological functional groups in

732 LGAT1 sedimentary core. Major temporal zones of change determined by

733 clustering analysis are shown by dotted lines, corresponding to Zone1 c. pre-

734 1870, Zone 2 c.1870-1914, Zone 3 1923-1990, and Zone 4 1991-2013. 


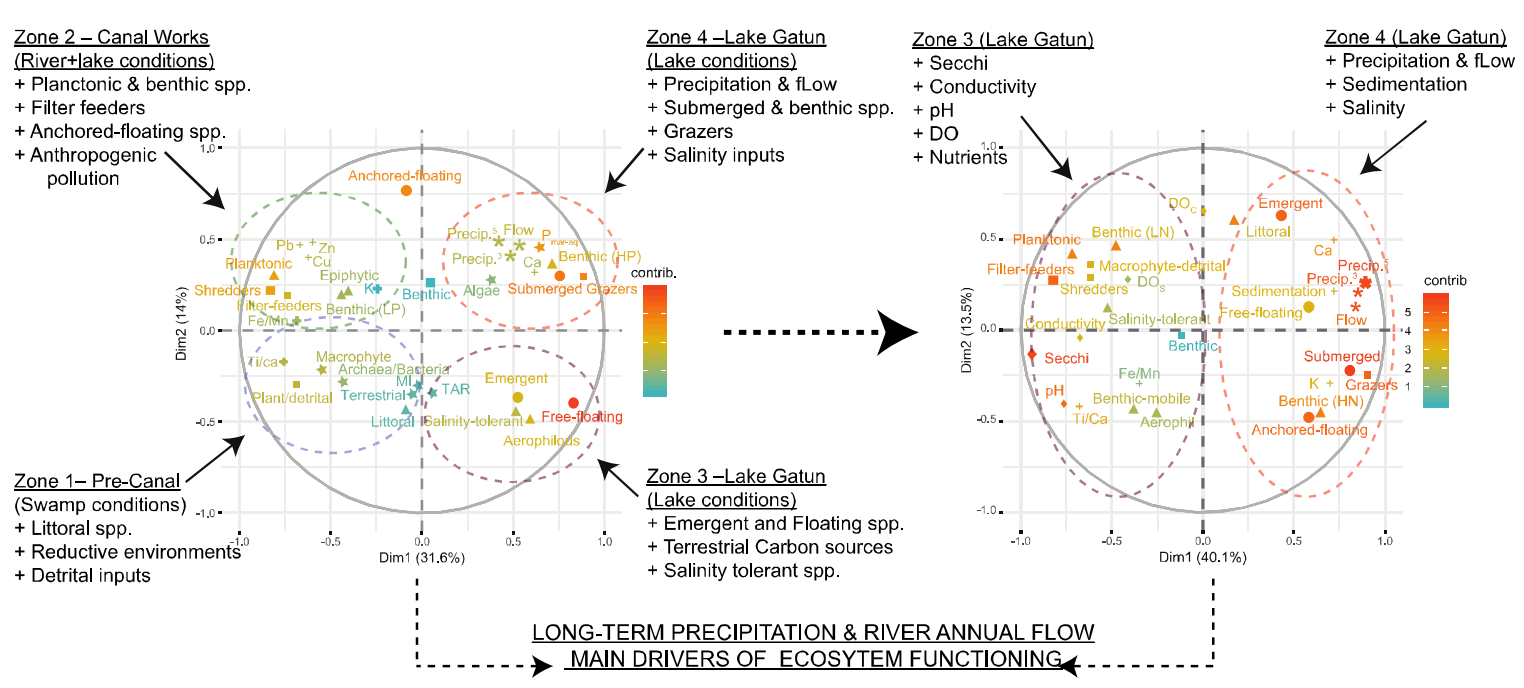

737 Figure 4. Multiple factor analysis (MFA) results for the time periods $c$. pre-

738 canal-2013 and 1969-2013. The analysis was run on hydro-climatic data

739 (precipitation and river flow-hash), biological data (macrophytes-circle, diatoms-

740 triangle, invertebrates-square), geochemical data (cross), biomarker data (star)

741 and water quality data (period 1969-2013-diamond). The contribution of each

742 variable in the analysis is indicated according to a color scale. Low nutrients (LN),

743 high nutrients $(\mathrm{HN})$, three years average precipitation data (Precip. $\left.{ }^{3}\right)$, five ars

744 average precipitation data (Precip. ${ }^{5}$ ), river annual flow (Flow). Sediments samples

745 within each major temporal zone of compositional change are encircled

746 according to Zone 1 c. pre-1870, Zone 2 c.1870-1914, Zone 3 1923-1990, and

747 Zone 4 1991-2013. 
748 Table 1. Historical environmental records of Lake Gatun. Historical data on

749 three years average precipitation data $\left(\right.$ Precip. $\left.^{3}\right)$, five years average precipitation

750 data (Precip. $^{5}$ ), and annual river flow in Gatun Lake for the periods 1930-2013,

751 and historical data on nitrates $\left(\mathrm{NO}_{3}\right)$, phosphates $\left(\mathrm{PO}_{4}\right)$, secchi depth,

752 conductivity, $\mathrm{pH}$, dissolved oxygen at the water surface $\left(\mathrm{DO}_{s}\right)$ and at the water

753 column $\left(\mathrm{DO}_{\mathrm{c}}<1 \mathrm{~m}\right.$ depth), and chlorophyll a (Chl-a) for the period 1969-2013.

\begin{tabular}{|c|c|c|c|c|c|c|c|c|c|c|c|}
\hline $\begin{array}{l}\text { Time } \\
\text { (yrs.) }\end{array}$ & $\begin{array}{l}\text { Precip. } \\
\quad 5 \\
(\mathrm{~mm})\end{array}$ & $\begin{array}{c}\text { Precip. } \\
(\mathrm{mm})\end{array}$ & $\begin{array}{c}\text { Annual } \\
\text { flow } \\
\text { (m3/s) }\end{array}$ & $\mathrm{pH}$ & $\begin{array}{c}\mathrm{DO}_{\mathrm{s}} \\
(\mathrm{mg} / \mathrm{L})\end{array}$ & $\begin{array}{c}\mathrm{DO}_{\mathrm{C}} \\
(\mathrm{mg} / \mathrm{L})\end{array}$ & $\begin{array}{c}\mathrm{NO}_{3} \\
(\mathrm{mg} / \mathrm{L})\end{array}$ & $\begin{array}{c}\mathrm{PO}_{4} \\
(\mathrm{mg} / \mathrm{L})\end{array}$ & $\begin{array}{c}\text { Cond. } \\
(\mu \mathrm{S} / \mathrm{cm} \\
)\end{array}$ & $\begin{array}{l}\text { Chl-a } \\
(\mu \mathrm{l} / \mathrm{L})\end{array}$ & $\begin{array}{l}\text { Secchi } \\
(\mathrm{cm})\end{array}$ \\
\hline 2013† & 2964 & 3381 & 41 & 6.41 & 6.44 & 5.25 & 0.04 & 0.01 & 42.34 & 2.31 & 146 \\
\hline $2011 \dagger$ & 2841 & 2778 & 38 & 6.35 & 6.60 & 5.12 & 0.07 & 0.01 & 47.86 & 3.22 & 150 \\
\hline $2009+$ & 2664 & 2640 & 31 & 6.50 & 6.48 & 5.01 & 0.03 & 0.00 & 49.38 & 4.18 & 167 \\
\hline $2008 \dagger$ & 2769 & 2741 & 31 & 6.59 & 6.28 & 4.23 & 0.03 & 0.01 & 55.62 & 5.09 & 177 \\
\hline $2006 \dagger$ & 2569 & 2685 & 29 & 6.56 & 6.25 & 3.51 & 0.04 & 0.02 & 55.62 & 2.89 & 212 \\
\hline $2005 †$ & 2620 & 2689 & 27 & 6.53 & 6.23 & 2.52 & 0.03 & 0.01 & 45.21 & 4.72 & 192 \\
\hline $2003+$ & 2593 & 2802 & 30 & 7.13 & 6.61 & 2.90 & 0.03 & 0.02 & 50.33 & & \\
\hline $2000 \dagger$ & 2688 & 2644 & 37 & 6.76 & 6.48 & 3.02 & 0.05 & & 49.92 & & \\
\hline $1993 \S$ & 2589 & 2669 & 28 & 7.39 & 6.22 & 1.94 & & 0.04 & 54.00 & & \\
\hline $1989 \S$ & 2517 & 2524 & 26 & & 8.66 & 4.94 & 0.03 & 0.04 & 44.88 & 2.05 & 393 \\
\hline $1978^{*}$ & 2508 & 2332 & 25 & 7.20 & 7.78 & & 0.06 & & 90.00 & 4.10 & 700 \\
\hline $1972^{*}$ & 2331 & 2371 & 26 & 7.56 & 8.00 & & 0.05 & 0.02 & 98.00 & & \\
\hline $1969^{*}$ & 2497 & 2444 & 27 & 7.21 & 5.59 & 5.12 & & & & & 530 \\
\hline 1955 & 2663 & 2859 & 29 & & & & & & & & \\
\hline 1930 & 2679 & 2488 & 27 & & & & & & & & \\
\hline
\end{tabular}

${ }^{*}$ ref-53; ${ }^{\S}$ ref-56; ${ }^{\dagger}$ ref-57; precipitation data were obtained from (Steve Paton,

755 pers. comm.) and annual flow data from ref-23. 